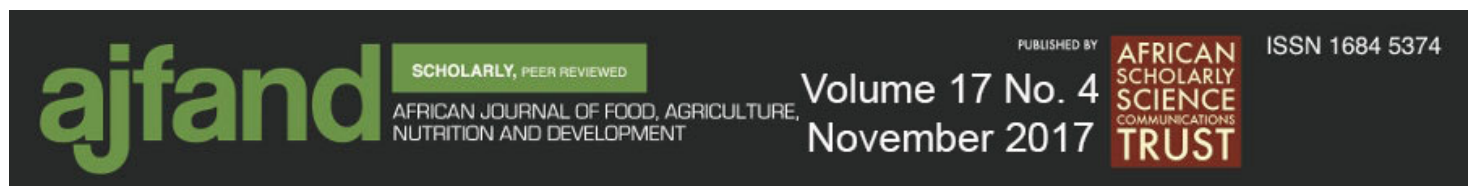

\title{
ASSESSMENT OF THE AGRONOMIC PRODUCTIVITY AND PROTEIN CONTENT IN 16 SOYBEAN GENOTYPES
}

$$
\text { Jephter BFM }{ }^{1} \text {, Mumba } \mathrm{P}^{2 *} \text { and JM Bokosi }{ }^{1}
$$

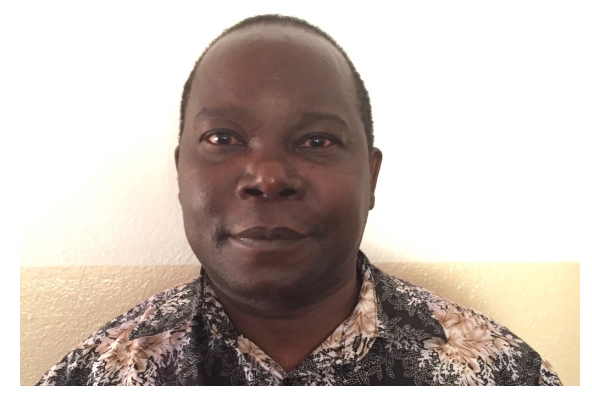

Mumba Peter

*Corresponding author email: mumbap01@yahoo.com

${ }^{1}$ Crop and Soil Science Department, Lilongwe University of Agriculture and Natural Resources, P.O. Box 219, Lilongwe, Malawi

${ }^{2}$ Basic Sciences Department, Lilongwe University of Agriculture and Natural Resources P.O. Box 219, Lilongwe, Malawi 


\begin{abstract}
Soybean is an important crop worldwide. It can be used for food, seed, fuel, vegetable oil, soy milk and is capable of biological nitrogen fixation. In Malawi, yields are generally low $(400-1000 \mathrm{Kg} / \mathrm{hectare})$ as opposed to a potential of $4,000 \mathrm{Kg}$ per hectare. Farmers grow varieties of which no protein content is known. An experiment was carried out in Malawi to assess the productivity and protein content of 16 different soybean genotypes. The genotypes included the newly released ones: TG X 1830-20E, UG-5 and TG X 1908-8Fand those released earlier: Magoye, Nasoko, Makwacha, Ocepala-4, TGX 1937-1F, TG X 1954-1F, TGX 1485-1D, TGX 1019-2EB, TGX 1835-10E, TGX 1440-1E, TGX 1904-6F, TGX 191013F, TGX 1910-14F. These genotypes were grown in plots of 5 meters by 4 meters each. The data was collected by field observations and lab experiments. The results showed that there was a significant genotypic improvement in some newly released varieties in terms of yield and other yield components. High grain yield and high number of branches per plant, number of pods per plant, podding height, harvest index, biological yield, dry matter content and 100 seeds weight were observed in the varieties TG X 1830-20E and UG-5. There was a significant difference $(\mathrm{p}<0.05)$ in yield per hectare and in protein content among the sixteen genotypes. Higher protein content was obtained in TGX 1830-20E, UG-5 and TG X 1908-8F than in the earlier approved ones. Among the genotypes, TGX 1830-20E, UG-5 and TGX 1908-8F were the most productive. The results showed that genotypes such as TGX 1485-1D had more protein content than those already released genotypes. The lowest protein content of $27.1 \%$ was found in Nasoko. Most of the newly released genotypes had the protein content ranging from $36 \%$ to $43 \%$. The results on the newly released varieties have shown that genetic improvement in yield and protein content are possible through deliberate effort in plant breeding and so farmers can selectively grow varieties with the desired traits either for protein production or for non-protein (protein food) production. In addition, food producing industries can easily choose varieties based on the type of food product to be produced. The information should also help Researchers to know which varieties to be used when producing new varieties looking at specific traits whether yield traits or protein content.
\end{abstract}

Key words: Soybean, genotype, productivity, protein content, traits, selection, variety, yield 


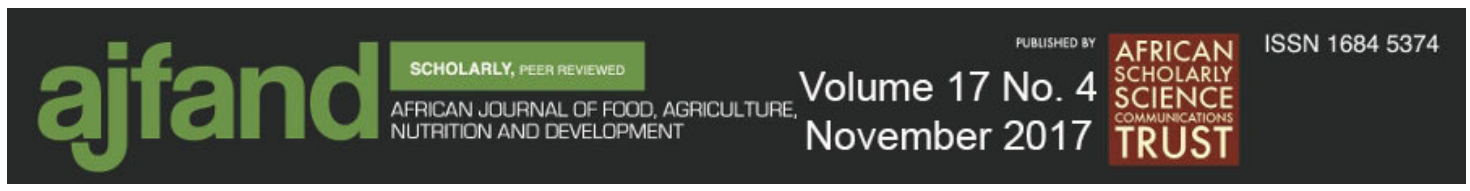

\section{INTRODUCTION}

Soybean (glycine max) is an erect, bushy leafy annual legume. Its importance is due to its high oil and protein contents. Soybeans are legumes that are rich in nutrients and high in protein and with very little saturated fats and no cholesterol, making them a good choice for a heart-healthy diet. Soybeans are used as feed for livestock and aquaculture and are also a good source of protein for the human diet and as a biofuel feedstock [1]. Soybean breeders have looked for genotypes with high oil and protein content along with high grain yield $[2,3]$. A strong indirect phenotypic correlation exists between protein and oil content of soybeans traits. In addition, variation in soybean germ plasm for protein content is significantly greater than that observed for total oil content [2]. Some field studies have shown that there is no significant relationship between seed yield and oil and protein contents of soybeans but there is an inverse significant relationship between oil and protein content [4]. Other studies, however, have shown that the inverse relationship between protein and oil contents of soybeans occurs when there is water deficiency [5]. The results of one study showed that protein content increased by 4.4 percentage points, while oil content decreased by 2.9 percentage points as a result of drought [6]. The experiment also showed that seeds from plants exposed to a high temperature $\left(35^{\circ} \mathrm{C}\right)$ during seed fill contained 4.0 percentage points more protein and 2.6 percentage points less oil than those exposed to lower temperature $\left(29^{\circ} \mathrm{C}\right)$. Numerous studies have shown that environmental stresses have a major impact on the nutritional composition of soybeans, indicating seed protein content, yield, viability, and vigor can be drastically reduced during growing seasons $[6,7,8,9,10]$. For example, some studies have shown that grain yield decreases under water stress conditions. Consequently, a decrease in oil and protein yields per unit area underwater stress is attributed to the reductions in grain yield per unit area $[5,10]$.

Reports have indicated that value-added grains and oilseeds have specific traits that have been genetically developed for specific end-use purposes, such as for corn dry and wet milling, snack food manufacturing, soybean oil refining, and peroxidase recovery from soybean hulls [11]. Furthermore, it has been stated that an average soybean container of $27 \mathrm{~kg}$ contains $35 \%$ protein, $18.5 \%$ oil, and $5 \%$ fiber, and yields $5 \mathrm{~kg}$ of oil and $22 \mathrm{~kg}$ of $44 \%$ protein meal [11]. However, not every $27 \mathrm{~kg}$ soybean container will give the same weight of oil and meal since there is considerable variability in the protein and oil content of soybeans among countries, states, regions within states, and among varieties.

In Malawi soybean is grown in most parts. However, it is grown on small scale and mostly by smallholder farmers. Due to high nutritional value of its seed, it is used in manufacturing many human foods such as margarine, cooking oil, salad oils, chocolate, meat substitutes (soy pieces), soy flour, green beans, roasted beans, and whole beans [12]. It is also used to manufacture some products such as soap, candles, glycerin, oil cloth and soybean oil cake. Many of soybean products are also used in the programs such as Early Child hood Nutrition Program, HIV and AIDS Nutritional program, Early School child hood Nutrition program. Furthermore, many food processing industries and governmental and nongovernmental organizations demand soybeans. 
There are so many soybean genotypes that are grown and used in Malawi. However, the problem comes on which genotype amongst these is the best in terms of protein content, oil content and productivity. Knowing these traits can help farmers, researchers, food processing industries, genetic engineers and some organizations to choose the right genotype to use based on the purpose intended. However, in Malawi, no research has been carried out on protein content and productivity of different soybean varieties.

The objective of this study was, therefore, to assess the agronomic productivity and protein content in soybean varieties. Specifically, the study was aimed at assessing the protein content, yield and yield components in sixteen soybean genotypes.

\section{MATERIALS AND METHODS}

The experiment was carried out at University of Malawi's Bunda College Farm in Malawi in 2010/2011 cropping season. Bunda College has coordinates of $14^{\circ} 1$ ' $17^{\prime \prime} \mathrm{S}$ and $33^{\circ} 48^{\prime} 07^{\prime}$ '. It lies at 1180 meters above sea level and receives an average annual rainfall of $900 \mathrm{~mm}$ and temperature ranges $20-27^{\circ} \mathrm{C}$. Sixteen soybean genotypes namely, Magoye, Nasoko, Makwacha, UG-5, Ocepala-4, TGX 1937-1F, TGX 1954-1F, TGX 1485-1D, TGX 1019-2EB, TGX 1830-20E, TGX 1835-10E, TGX 1440-1E, TGX 19046F, TGX-1908-8F, TGX 1910-13F, and TGX 1910-14F were grown. All varieties were grown in plots of four ridges, each of five meters long and the spacing between the ridges was $75 \mathrm{~cm}$. Three plants per station were planted at $30 \mathrm{~cm}$ distance between planting stations. There was a distance of 1 meter from one plot to the other and 2 meters distance from one block to the other. The whole trial was planted on the same date. The field layout is presented in Table 1.

\section{Field Data collection and Analysis}

Data collection started after planting in December. The first data collected were days to emergence, germination percentage for each variety. The other data were collected during the production period of 120 days and these included disease resistance and occurrence, flowering date, days to maturity, podding height, lodging resistance, number of pods per plant, number of branches per plant, plant height to maturity. These data were collected until the plants reached harvest time, which took a period of 135 days. After harvesting, the following data were obtained as follows:

Biological yield per plant (g): Total biomass above ground, shoot weights Grain yield per plant (g): Weight of grain per plant adjusted to $12 \%$ moisture content Yield per hectare $(\mathrm{kg})$ : Grain weight/ha adjusted to $12 \%$ moisture content Harvest index (\%): Economical yield/ Biological yield x 100 100seeds weight $(\mathrm{g})$ : Wt of 100 seeds obtained from a balance Dry matter: Wt of material after drying for $48 \mathrm{hrs}$ in the oven at $72^{\circ} \mathrm{C}$

\section{Chemical Analysis}

Protein content of the soybean seeds was analyzed by the Kjeldahl method [13]. One gram of ground sample was placed into a digestion flask after which $12 \mathrm{ml}$ concentrated sulphuric acid $\left(\mathrm{H}_{2} \mathrm{SO}_{4}\right)$ and seven grams of potassium sulphate $\left(\mathrm{K}_{2} \mathrm{SO}_{4}\right)$ were added. After digestion and cooling the mixture was titrated and percent crude protein calculated. 


\section{Statistical Analysis}

All data were analyzed using the Gen STAT from which means, mode, variance, lowest significant differences, coefficient of variation and standard deviation were derived. One way ANOVA mathematical model was used in analysis of the data using the model indicated below:

$$
\begin{aligned}
& \mathrm{Y}_{\mathrm{ijk}}=\mu+\mathrm{B}_{\mathrm{i}+} \mathrm{T}_{\mathrm{j}}+\sum_{\mathrm{ijk}} \text {, where: } \\
& \mathrm{Y}_{\mathrm{ijkk}}=\text { observed performance on the } \mathrm{jth} \text { block for ith line } \\
& \mu=\text { overall mean } \\
& \mathrm{B}_{\mathrm{i}}=\text { block effect } \\
& \mathrm{T}_{\mathrm{j}}=\text { Treatment } \text { effect } \\
& \sum_{\mathrm{ijk}=} \text { Random error component }
\end{aligned}
$$

\section{RESULTS}

The percent germination, lodging resistance, number of branches per plant, podding height and number of pods per plant are given in Table 2. The germination percentage was not significantly different among the 16 varieties of soybeans. The grand mean germination percentage was $67.6 \%$. The lodging resistance among the 16 varieties did not differ significantly. The number of branches was significantly different among the varieties $p<0.001$. The highest number of 7 branches per plant was found in TGX 1440-1E, and this was followed by 6 branches per plant in TGX 1830-20E, TGX 1910-14F, TGX 1954-1F, TGX 1937-1F, TGX 1904-6F, TGX 1910-13F and TGX 1908-8F. The lowest number of branches/plant was 4 and was recorded in Makwacha, Ocepala-4, TGX 1019-2EB and TGX $1835-10 \mathrm{E}$. The grand mean number of branches per plant was 5. The podding height was significantly different among the 16 genotypes $(\mathrm{P}<0.003$. The grand mean podding height was $32.06 \mathrm{~cm}$ with the highest podding height being $39.77 \mathrm{~cm}$ observed for the variety TGX 1908-8F, followed by TGX 1830-20E. TGX 1937-1F and TGX 1954-1F had a podding height of $37 \mathrm{~cm}$. The number of pods per plant differed significantly among genotypes $(\mathrm{p}<0.009)$. The grand mean was 28 pods per plant. The highest number of pods per plant was 40 which were found in the variety TGX $1830-20 \mathrm{E}$ and this was followed by TGX 1954-1F (38 pods), TG X 1937-1F (37 pods), TGX 1440-1E (37 pods), TGX 1908-8F (35 pods), and TGX 1910-13F (34 pods). The lowest number of pods was 18 which were found in two varieties namely TGX 1835-10E and TGX 1019-2EB. The already approved varieties namely:- Makwacha, Magoye, Nasoko and Ocepala-4did not do well as compared to the other newly released varieties in terms of number of pods per plant.

The biological yield per plant, dry matter content, water content per plant, grain yield per plant and grain yield per plot are given in Table 3 . The highest biological yield per plant was $38.2 \mathrm{~g}$ found in TGX 1830-20E followed by 29.8g in UG-5, 25.9g in TGX 1440-1E and $23.6 \mathrm{~g}$ in TGX 1908-8F. The highest dry matter content per plant was $25.7 \mathrm{~g}$ found in TGX 1830$20 \mathrm{E}$ followed by $19.7 \mathrm{~g}$ in UG-5, 17.9g in TGX 1908-8F and 16.7g in Nasoko. The lowest dry matter content per plant was $8.7 \mathrm{~g}$ found in Makwacha and TGX 1835-10E. The highest water content was $38.4 \%$ observed in Makwacha, followed by $36.4 \%$ in TGX $1835-10 \mathrm{E}, 35.4 \%$ in UG-5, 33.6\% in Nasoko, $31.6 \%$ in TGX 1485 1D. The lowest water content $14.9 \%$ was found in TGX 1904-6F. The approved varieties have more water content than the unapproved ones. 


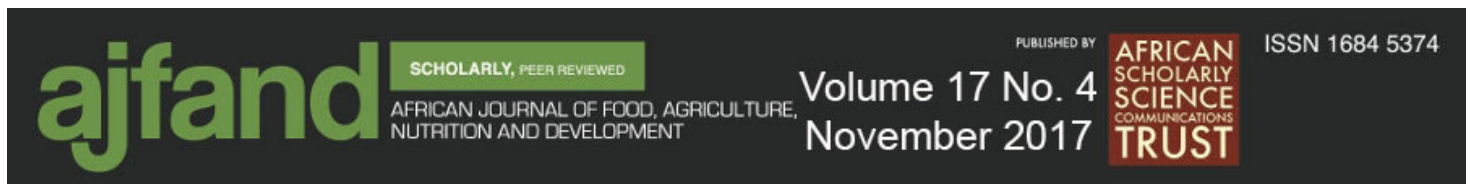

The results show that grain yield per plant differed significantly among the varieties $(p<0.05)$. The highest grain yield per plant was $11.6 \mathrm{~g}$ which was found in TGX $183020 \mathrm{E}$ and $11.1 \mathrm{~g}$ found in UG-5. The lowest grain yield was 3.5g found in Magoye and TGX 1954-1F, 3.7g found in Makwacha.

The grain yield per hectare, the 100-seed weights, the protein contents, harvest index and the disease resistance are given in Table 4 . The grain yield per hectare was significantly different among the 16 varieties $(\mathrm{p}<0.05)$ with a coefficient of variation of $39.1 \%$. The grand mean for grain yield per hectare was $319.7 \mathrm{~kg}$. The highest grain yield per hectare was $572.4 \mathrm{~kg}$, which was found in TGX $1830-20 \mathrm{E}$ followed by $540.6 \mathrm{~kg}$ in UG-5. The lowest grain yield per hectare was $167.1 \mathrm{~kg}$ found in TGX $1835-10 \mathrm{E}$. The highest 100 seeds weight was $17.46 \mathrm{~g}$ observed in Nasoko followed by $17.30 \mathrm{~g}$ in Makwacha, $16.75 \mathrm{~g}$ in UG-5 and 16.06g in Ocepala-4. The protein content was significantly different among the 16 genotypes $(\mathrm{p}<0.05)$. The grand mean protein content was $38.4 \%$. The highest protein content was $49.4 \%$ which was found in TGX 1485 -1D, followed by $43.4 \%$ in TGX $1019-2 \mathrm{~EB}, 42.4 \%$ in TGX $1910-14 \mathrm{~F}, 41.9 \%$ in TG X $1830-20 \mathrm{E}, 39.4 \%$ in TGX 1835-10E, 39.2\% in UG-5 and 39.0\% in TGX 1904-6F. The lowest protein content was $27.1 \%$ in Nasoko followed by $33.4 \%$ in Makwacha and $33.5 \%$ in Ocepala-4. TGX 1830-20E, UG-5 and TGX 1908-8F had higher protein content than the genotypes that were released earlier. The highest harvest index was $0.45 \mathrm{~g}$ found in Ocepala4 followed by 0.44 in TGX $1885-10 \mathrm{E}$ and 0.41 in TGX 1904-6F. The lowest harvest index was 0.20 found in TGX 1954-1F. The disease resistance was significantly different among the varieties $(\mathrm{p}<0.05)$. The most affected variety was TGX 1440-1E with 37 plants affected followed by TGX 1835-10E with 34 plants affected, TGX 1910-13F with 33 plants affected, and TGX 1910-14F with 31 plants affected. The least affected variety was UG-5 with only 3 plants affected.

\section{DISCUSSION}

There were significant differences among the genotypes in most of the traits studied. The results on grain yield suggest that there was an improvement in the productivity of some varieties. More significant is an improvement in productivity in terms of grain yield in TG X 1830-20E and UG-5. This means that given the good soil management practices, these genotypes can do better than all the varieties studied in this research. The varieties with grain yield in the range 300-400kg per hectare, which were: Magoye, Nasoko, Ocepala-4, TGX 1937-1F, TG X 1954-1F, TGX 1904-6F, TGX 1908-8F and TGX 1019-2EB, can also do well given right conditions and adequate rainfall. Those varieties with grain yield within 100$300 \mathrm{~kg}$ per hectare had low productivity. This means that even with the right conditions and adequate rainfall they cannot do as well as TGX 1830-20E and UG-5. Two genotypes specifically TGX $1830-20 \mathrm{E}$ and UG-5 are more improved in terms of grain yield than all other genotypes. None of the varieties including those already grown by farmers reached the potential yield of 4000/ha. This could be a result of weather conditions during production period. The rains did not come in a pattern required by the crops for growth and production. There was a dry spell during the time the crops were flowering and this caused a great loss in yield. Most of the flowers aborted due to lack of adequate water in the plants. In addition, most of the pods did not successfully fill and also, there was a problem with pests which attacked the grains as soon as the pods were filled. All these factors could have contributed to the observed low yields. Studies by some researchers also showed that water stress in 
soybean stands resulted in abortion of flowers and pods and this reduced yield [5]. Reports have indicated that the more the number of pods per plant and higher leaf area, the higher yields per plant of soybeans and, as such, the potential of genotypes should be utilized as the protein content is positively and significantly correlated with yield and, therefore, both characters should be combined in the same genotype [14].

The highest harvest index found in Ocepala- 4 means that this variety has highest capacity of partitioning or converting biomass into commercial yield which is grain yield. The least harvest index observed in TGX 1954-1F means that this variety has the lowest capacity to convert biomass into yield. Also the genotypes, Magoye, Makwacha, TGX 1910-14F, TGX 1440-1E, TGX 1485-1D and TGX 1835-10E have low capacity to convert biomass into yield as they have small harvest index.

The fact that the old released varieties did not have high protein content as compared to the newly improved ones could be due to the differences in genotypic composition of the varieties. This, in turn, suggests that there is a genotypic improvement in the newly released genotypes as compared to the already approved varieties. For both grain yield and protein content, most of the newly released genotypes showed improvement. However, not all these newly released genotypes showed improvement in yield and protein content.

Considering all the yield component traits namely, number of branches per plant, number of pods per plant, podding height, dry matter content per plant, biological yield per plant, harvest index and grain yield per plant as well as per plot and per hectare, TG X 1830-20E was the best in terms of all these traits. It proved to be the best improved genotype compared to those already released. The other genotype which also showed some improvement was UG-5 as it had high values of podding height, biological yield, dry matter content, 100seeds weight, harvest index and grain yield both per plant and per hectare. High values in terms of number of branches per plant, number of pods per plant, podding height, dry matter content per plant, biological yield per plant, and harvest index were observed in the variety TG X 1908-8F. However, it showed low grain yield values per plant, per plot as well as per hectare. The genotypes which had the lowest values in most of the yield component traits were TG X 183510E, Makwacha, Magoye, Nasoko, Ocepala-4, TG X 1019-2EB and TG X 1904-6F. Studies have shown that there is a significant and positive correlation between seed yield per plant with number of clusters per plant, number of pods per plant, biological yield per plant and harvest index at both the genotypic and phenotypic levels and such interrelationship can serve as indicator characters for seed yield improvement [15]. Studies on the relations between yield and number of pods per plant, number of seeds per pod and 100-seed weight showed that the number of pods per plant and 100-seed weight correlated strongly and negatively on yield, and the same was true for days to flowering and number of branches on number of pods per plant, days to flowering, days from flowering to maturity on 100-seed weight [16].

The results have indicated that the genotypes, UG-5 and TGX 1830-20E had high productivity in terms of grain yield also had high protein content. This observation is in agreement with the results from other similar studies [5], where a high positive correlation between protein content and yield of soybeans was observed although in studies by other researchers, no such significant relationship was observed between the two [5,17]. However, the genotypes, TGX 1910-14F, and TGX 1485-1D had high protein content but with low 
productivity. Some genotypes were found to have average productivity but with low protein content. These genotypes include: Nasoko, Ocepala-4 and TGX 1937-1F. The genotypes, TGX 1910-13F and TGX 1835-10E had average protein content and low productivity. The protein contents of TGX 1954-1F (38.8\%), Magoye (37.7\%), TGX 1904-6F (39\%) and TG X 1908-8F (38.1\%) were relatively high but these genotypes had only average productivity. Lastly, the genotypes, TGX 1440-1E and Makwacha were found to have low protein content $(36.6 \%, 33.4 \%$, respectively) and low productivity.

\section{CONCLUSION}

The results have shown that while the genotypes, UG-5 and TGX 1830-20E had high productivity in terms of grain yield and high protein content, the genotypes TGX 1910-14F, and TGX 1435-1D were found to have high protein content but with low productivity. Furthermore, the genotypes namely, Nasoko, Ocepala-4 and TGX 1937-1F were found to have average productivity but with low protein content and the genotypes, TG X 1910-13F and TGX $1835-10 \mathrm{E}$ were found to have average protein content and low productivity. The genotypes, TGX 1954-1F and Magoye were found to have high protein content but with average productivity. Finally, the genotypes, TGX 1904-6F and TGX 1908-8F were found to have average protein content and average productivity and the genotypes, TGX 1440-1E and Makwacha were found to have low protein content and low productivity. The results have shown that there is a genotypic improvement in some newly released genotypes in terms of grain yield and protein content. For high protein and yield, TGX 1954-1F and Magoye should be recommended to farmers. The study shows that farmers can selectively grow varieties with the desired traits either for protein production or for non-protein food production. In addition, the food industry can easily choose varieties to buy from farmers based on the type of food product to be processed. The information should also help inform researchers and genetic engineers to know which varieties to be used for specific traits whether for yield or for protein content. 


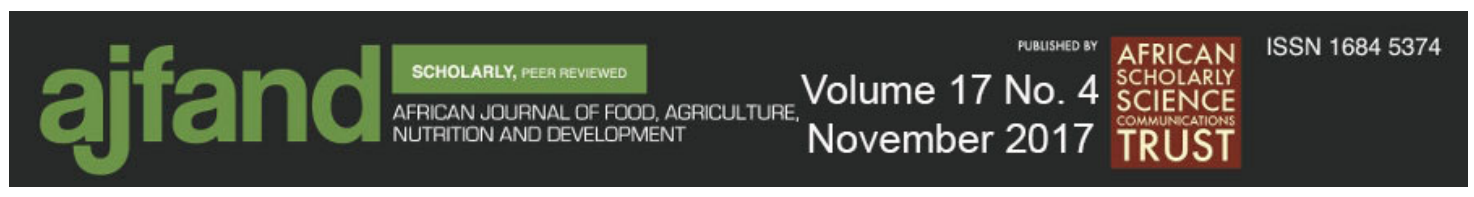

Table 1: Field layout

\begin{tabular}{|l|l|l|l|}
\hline Plot number & Block 1 & Block 2 & Block 3 \\
\hline Plot 1 & Ocepala-4 & TGX 1937-1F & Makwacha \\
\hline Plot 2 & Nasoko & TGX 1019-2EB & TGX 1904-6F \\
\hline Plot 3 & UG-5 & Nasoko & TGX 1835-10E \\
\hline Plot 4 & TGX 1910-13F & TGX 1954-1F & TGX 1440-1E \\
\hline Plot 5 & TGX 1835-10E & Ocepala-4 & Magoye \\
\hline Plot 6 & Magoye & Makwacha & TGX 1937-1F \\
\hline Plot 7 & TGX 1908-8F & TGX 1830-20E & TGX 1485-1D \\
\hline Plot 8 & Makwacha & UG-5 & TGX 1954-1F \\
\hline Plot 9 & TGX 1910-14F & TGX 1835-10E & Nasoko \\
\hline Plot 10 & TGX 1954-1F & TGX 1485-1D & TGX 1830-20E \\
\hline Plot 11 & TGX 1440-1E & TGX 1910-13F & UG-5 \\
\hline Plot 12 & TGX 1904-6F & TGX 1908-8F & TGX 1910-14F \\
\hline Plot 13 & TGX 1485-1D & TGX 1440-1E & Ocepala-4 \\
\hline Plot 14 & TGX 1019-2EB & Magoye & TGX 1908-8F \\
\hline Plot 15 & TGX 1830-20E & TGX 1910-14F & TGX 1019-2EB \\
\hline Plot 16 & TGX 1937-1F & TGX 1904-6F & TGX 1910-13F \\
\hline
\end{tabular}




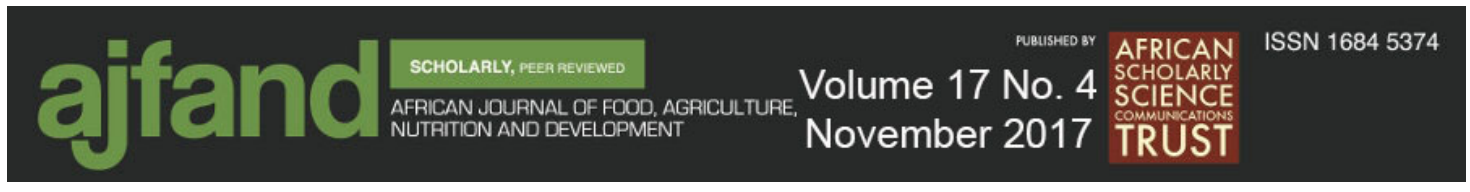

Table 2: Germination \%, lodging resistance, number of branches/plant, podding height and number of pods per plant

\begin{tabular}{|c|c|c|c|c|c|}
\hline VARIETY & $\begin{array}{l}\text { Germination } \\
\%\end{array}$ & $\begin{array}{l}\text { Lodging } \\
\text { resistance } \\
(0-9 \text { scale })\end{array}$ & $\begin{array}{l}\text { No. } \\
\text { branches/plant }\end{array}$ & $\begin{array}{l}\text { Podding } \\
\text { height }(\mathrm{cm})\end{array}$ & $\begin{array}{l}\text { No. pods } \\
\text { /plant }\end{array}$ \\
\hline Makwacha & $60.8^{b}$ & $3^{\mathrm{a}}$ & $4^{\mathrm{c}}$ & $31.27^{b}$ & $24^{\mathrm{b}}$ \\
\hline Magoye & $60.8^{\mathbf{b}}$ & $7^{\mathrm{a}}$ & $5^{\mathrm{bc}}$ & $29.80^{\mathrm{bc}}$ & $29^{\mathrm{ab}}$. \\
\hline Nasoko & $60.3^{b}$ & $3^{a}$ & $5^{\mathrm{bc}}$ & $35.87^{\mathrm{ab}}$ & $20^{\mathrm{b}}$ \\
\hline UG-5 & $69.1^{\mathrm{ab}}$ & $0^{\mathrm{a}}$ & $5^{\mathrm{bc}}$ & $36.83^{\mathrm{ab}}$ & $27^{\mathrm{ab}}$ \\
\hline Ocepala -4 & $69.9^{\mathbf{a b}}$ & $2^{a}$ & $4^{\mathrm{c}}$ & $26.33^{b c}$ & $22^{b}$ \\
\hline $\begin{array}{l}\text { TG X } 1910 \text { - } \\
14 F\end{array}$ & $52.9^{b}$ & $7^{\mathrm{a}}$ & $6^{\mathrm{ab}}$ & $27.37^{b c}$ & $23^{\mathrm{b}}$ \\
\hline $\begin{array}{l}\text { TG X 1954- } \\
\text { 1F }\end{array}$ & $66.3^{b}$ & $7^{\mathrm{a}}$ & $6^{\mathrm{ab}}$ & $37.63^{\mathrm{ab}}$ & $38^{\mathrm{a}}$ \\
\hline $\begin{array}{l}\text { TG X } 1937 \\
\text { 1-F }\end{array}$ & $75.8^{\mathbf{a b}}$ & $2^{\mathrm{a}}$ & $6^{\mathrm{ab}}$ & $32.90^{\mathrm{ab}}$ & $37^{\mathrm{ab}}$ \\
\hline $\begin{array}{l}\text { TG X 1019- } \\
\text { 2EB }\end{array}$ & $91.7^{\mathrm{a}}$ & $2^{a}$ & $4^{\mathrm{c}}$ & $29.57^{b c}$ & $18^{\mathrm{b}}$ \\
\hline $\begin{array}{l}\text { TG X 1440- } \\
1 E\end{array}$ & $65.4^{\mathrm{b}}$ & $7^{\mathrm{a}}$ & $7^{\mathrm{a}}$ & $31.67^{\mathbf{b}}$ & $37^{\mathrm{ab}}$ \\
\hline $\begin{array}{l}\text { TG X 1835- } \\
\text { 10E }\end{array}$ & $59.0^{\mathrm{b}}$ & $5^{\mathrm{a}}$ & $4^{c}$ & $22.87^{\mathfrak{c}}$ & $18^{\mathrm{b}}$ \\
\hline $\begin{array}{l}\text { TG X 1485- } \\
\text { 1D }\end{array}$ & $73.0^{\mathbf{a b}}$ & $1^{\mathrm{a}}$ & $5^{\mathrm{bc}}$ & $28.77^{b c}$ & $23^{b}$ \\
\hline $\begin{array}{l}\text { TG X 1830- } \\
20 E\end{array}$ & $73.2^{\mathrm{ab}}$ & $2^{a}$ & $6^{\mathrm{ab}}$ & $39.30^{\mathrm{a}}$ & $40^{\mathrm{a}}$ \\
\hline $\begin{array}{l}\text { TG X 1904- } \\
\text { 6F }\end{array}$ & $68.3^{\mathbf{a b}}$ & $2^{a}$ & $5^{\mathrm{bc}}$ & $30.03^{\mathrm{b}}$ & $28^{\mathrm{ab}}$ \\
\hline $\begin{array}{l}\text { TG X 1908- } \\
8 F\end{array}$ & $72.7^{\mathbf{a b}}$ & $3^{a}$ & $6^{\mathrm{ab}}$. & $39.77^{\mathbf{a}}$ & $35^{\mathrm{ab}}$. \\
\hline $\begin{array}{l}\text { TG X 1910- } \\
\text { 13F }\end{array}$ & $62.1^{\mathrm{b}}$ & $3^{a}$ & $6^{\mathrm{ab}}$ & $33.07^{\mathrm{ab}}$ & $34^{\mathrm{ab}}$ \\
\hline Grand Mean & 67.6 & 4 & 5 & 32.06 & 28. \\
\hline F-Prob & 0.319 & 0.671 & $<.001$ & 0.003 & 0.009 \\
\hline $\begin{array}{l}\text { LSD (0.05) } \\
\text { CV\% }\end{array}$ & 23.65 & 7.3 & 1.4 & 7.741 & 13.2 \\
\hline CV\% & 21.0 & 125.8 & 15.7 & 14.5 & 28.1 \\
\hline
\end{tabular}

Means with different letters in a column are significantly different $(p<0.05)$ 


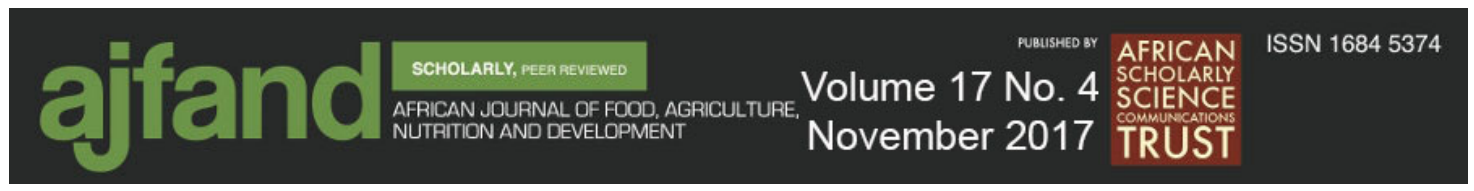

Table 3: Biological yield/plant, dry matter content/plant, water content/plant, grain yield/plant and grain yield/plot

\begin{tabular}{|c|c|c|c|c|c|}
\hline VARIETY & $\begin{array}{l}\text { Biological } \\
\text { yield } \\
(\mathrm{g}) / \mathrm{plant}\end{array}$ & $\begin{array}{l}\text { Dry matter } \\
\text { content } \\
\text { (g)/plant }\end{array}$ & $\begin{array}{l}\text { Water } \\
\text { content } \\
(\%) / \text { plant }\end{array}$ & $\begin{array}{l}\text { Grain } \\
\text { yield } \\
\text { (g)/plant }\end{array}$ & $\begin{array}{l}\text { Grain } \\
\text { yield } \\
\text { (g)/plot }\end{array}$ \\
\hline Makwacha & $13.9^{b}$ & $8.7^{b}$ & $38.4^{\mathrm{a}}$ & $3.7^{\mathrm{b}}$ & $208.0^{b}$ \\
\hline Magoye & $12.5^{\mathrm{b}}$ & $9.2^{\mathrm{ab}}$ & $25.2^{\mathrm{ab}}$ & $3.5^{\mathrm{b}}$ & $365.3^{b}$ \\
\hline Nasoko & $21.4^{\mathrm{b}}$ & $16.7^{\mathrm{ab}}$ & $33.6^{\mathrm{a}}$ & $8.0^{\mathrm{ab}}$ & $376.8^{\mathrm{b}}$ \\
\hline UG-5 & $29.8^{\mathrm{ab}}$ & $19.7^{\mathrm{a}}$ & $35.4^{\mathrm{a}}$ & $11.1^{\mathrm{ab}}$ & $648.7^{\mathrm{ab}}$ \\
\hline Ocepala -4 & $21.8^{\mathrm{b}}$ & $15.9^{\mathrm{ab}}$ & $27.4^{\mathrm{ab}}$ & $9.7^{\mathrm{ab}}$ & $471.6^{\mathrm{ab}}$ \\
\hline $\begin{array}{l}\text { TG X } 1910 \\
-14 F\end{array}$ & $16.0^{\mathrm{b}}$ & $10.9^{\mathrm{ab}}$ & $26.3^{\mathrm{ab}}$ & $4.3^{\mathrm{b}}$ & $261.8^{\mathrm{b}}$ \\
\hline $\begin{array}{l}\text { TG X 1954- } \\
\text { 1F }\end{array}$ & $19.8^{\mathrm{b}}$ & $14.1^{\mathrm{ab}}$ & $26.6^{\mathrm{ab}}$ & $3.5^{\mathrm{b}}$ & $434.1^{\mathrm{b}}$ \\
\hline $\begin{array}{l}\text { TG X } 1937 \\
1-F\end{array}$ & $12.1^{\mathrm{b}}$ & $9.3^{\mathrm{ab}}$ & $22.8^{\mathrm{ab}}$ & $4.7^{\mathrm{b}}$ & $390.5^{\mathrm{b}}$ \\
\hline $\begin{array}{l}\text { TG X 1019- } \\
\text { 2EB }\end{array}$ & $19.7^{\mathrm{b}}$ & $14.4^{\mathrm{ab}}$ & $23.2^{\mathrm{ab}}$ & $6.7^{\mathrm{b}}$ & $375.0^{\mathrm{b}}$ \\
\hline $\begin{array}{l}\text { TG X 1440- } \\
1 E\end{array}$ & $25.9^{\mathrm{ab}}$ & $16.9^{\mathrm{ab}}$ & $30.7^{\mathrm{ab}}$ & $7.0^{\mathrm{ab}}$ & $278.2^{\mathrm{b}}$ \\
\hline $\begin{array}{l}\text { TG X 1885- } \\
\text { 10E }\end{array}$ & $14.4^{\mathrm{b}}$ & $8.7^{\mathrm{b}}$ & $36.4^{\mathrm{a}}$ & $4.7^{\mathrm{b}}$ & $200.6^{\mathrm{b}}$ \\
\hline $\begin{array}{l}\text { TG X 1485- } \\
\text { 1D }\end{array}$ & $21.7^{\mathrm{b}}$ & $15.1^{\mathrm{ab}}$ & $31.6^{\mathrm{a}}$ & $6.5^{\mathrm{b}}$ & $322.6^{\mathrm{b}}$ \\
\hline $\begin{array}{l}\text { TG X 1830- } \\
20 E\end{array}$ & $38.2^{\mathrm{a}}$ & $25.7^{\mathrm{a}}$ & $29.2^{\mathrm{ab}}$ & $11.6^{\mathrm{a}}$ & $686.9^{\mathrm{a}}$ \\
\hline $\begin{array}{l}\text { TG X 1904- } \\
6 F\end{array}$ & $13.4^{\mathrm{b}}$ & $11.4^{\mathrm{ab}}$ & $14.9^{\mathrm{b}}$ & $5.6^{\mathrm{b}}$ & $401.3^{\mathrm{b}}$ \\
\hline $\begin{array}{l}\text { TG X 1908- } \\
8 F\end{array}$ & $23.6^{\mathrm{b}}$ & $17.9^{\mathrm{a}}$ & $24.6^{\mathrm{ab}}$ & $7.8^{\mathrm{ab}}$ & $447.3^{\mathrm{ab}}$ \\
\hline $\begin{array}{l}\text { TG X 1910- } \\
13 F\end{array}$ & $19.5^{\mathrm{b}}$ & $16.2^{\mathrm{ab}}$ & $25.2^{\mathrm{ab}}$ & $4.8^{\mathrm{b}}$ & $269.5^{\mathrm{b}}$ \\
\hline $\begin{array}{l}\text { Grand } \\
\text { Mean }\end{array}$ & 20.2 & 14.4 & 28.2 & 6.4 & 383.6 \\
\hline F-Prob & 0.045 & 0.034 & 0.395 & 0.014 & 0.015 \\
\hline LSD (0.05) & 14.04 & 9.07 & 16.50 & 4.72 & 250.21 \\
\hline CV\% & 41.6 & 37.7 & 35.1 & 43.9 & 39.1 \\
\hline
\end{tabular}

Means with different letters in a column are significantly different $(p<0.05)$ 


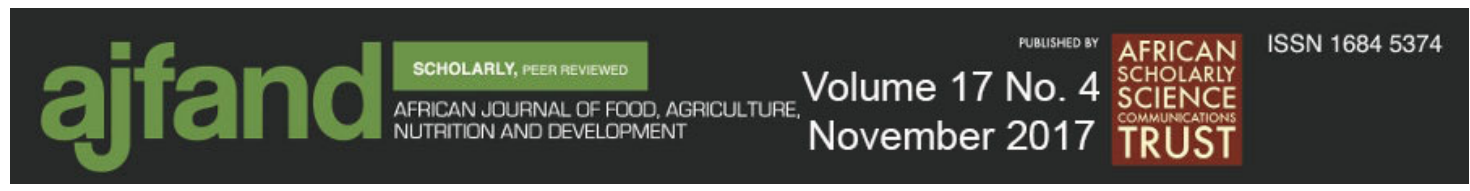

Table 4: Grain yield/hectare, 100 seeds weight, protein content, harvest index and disease resistance

\begin{tabular}{|c|c|c|c|c|c|}
\hline Variety & $\begin{array}{l}\text { Grain yield } \\
\text { (Kg)/hectare }\end{array}$ & $\begin{array}{l}100 \text { seeds } \\
\text { weight }(g)\end{array}$ & $\begin{array}{l}\text { Protein } \\
\text { content }(\%)\end{array}$ & $\begin{array}{l}\text { Harvest } \\
\text { index }(\%)\end{array}$ & $\begin{array}{l}\text { Disease } \\
\text { resistance } \\
\text { (plants } \\
\text { affected) }\end{array}$ \\
\hline Makwacha & $173.4^{b}$ & $17.30^{\mathrm{a}}$ & $33.4^{\mathrm{c}}$ & $0.251^{b}$ & $18.67^{\mathrm{ab}}$ \\
\hline Magoye & $304.4^{\mathrm{b}}$ & $10.67^{\mathrm{c}}$ & $37.7^{\mathrm{c}}$ & $0.295^{\mathrm{ab}}$ & $12.33^{b}$ \\
\hline Nasoko & $314.0^{\mathrm{b}}$ & $17.46^{\mathrm{a}}$ & $27.1^{d}$ & $0.360^{\mathrm{ab}}$ & $18.00^{\mathrm{ab}}$ \\
\hline UG-5 & $540.6^{\mathrm{ab}}$ & $16.75^{\mathrm{a}}$ & $39.2^{\mathrm{bc}}$ & $0.365^{\mathrm{ab}}$ & $3.33^{\mathrm{b}}$ \\
\hline Ocepala -4 & $393.0^{\mathrm{ab}}$ & $16.06^{\mathrm{a}}$ & $33.5^{\mathrm{c}}$ & $0.445^{\mathrm{a}}$ & $10.67^{b}$ \\
\hline TG X 1910 & $218.2^{\mathrm{b}}$ & $12.09^{b c}$ & $42.4^{b c}$ & $0.298^{\mathrm{ab}}$ & $31.33^{\mathrm{ab}}$ \\
\hline $\begin{array}{l}-14 F \\
\text { TG X 1954- } \\
\text { 1F }\end{array}$ & $361.8^{\mathrm{b}}$ & $12.54^{\mathrm{bc}}$ & $38.8^{\mathrm{bc}}$ & $0.197^{\mathrm{b}}$ & $18.67^{\mathrm{ab}}$ \\
\hline $\begin{array}{l}\text { TG X } 1937 \\
1-F\end{array}$ & $325.4^{\mathrm{b}}$ & $9.91^{\mathrm{c}}$ & $36.5^{\mathrm{c}}$ & $0.389^{\mathrm{ab}}$ & $22.00^{\mathrm{a}}$ \\
\hline $\begin{array}{l}\text { TG X 1019- } \\
\text { 2EB }\end{array}$ & $312.5^{\mathrm{b}}$ & $12.03^{b c}$ & $43.4^{\mathrm{bc}}$ & $0.367^{\mathrm{ab}}$ & $26.67^{\mathrm{ab}}$ \\
\hline $\begin{array}{l}\text { TG X 1440- } \\
1 \mathrm{E}\end{array}$ & $231.9^{\mathrm{b}}$ & $12.65^{b c}$ & $36.6^{c}$ & $0.292^{\mathrm{ab}}$ & $37.33^{\mathrm{a}}$ \\
\hline $\begin{array}{l}\text { TG X 1885- } \\
10 E\end{array}$ & $167.1^{\mathrm{b}}$ & $13.27^{\mathrm{b}}$ & $39.4^{b c}$ & $0.444^{\mathrm{a}}$ & $34.00^{\mathrm{ab}}$ \\
\hline $\begin{array}{l}\text { TG X 1485- } \\
\text { 1D }\end{array}$ & $268.9^{\mathrm{b}}$ & $10.14^{\mathrm{c}}$ & $49.4^{\mathrm{a}}$ & $0.291^{\mathrm{ab}}$ & $25.33^{\mathrm{ab}}$ \\
\hline $\begin{array}{l}\text { TG X 1830- } \\
20 E\end{array}$ & $572.4^{\mathrm{a}}$ & $10.98^{\mathrm{c}}$ & $41.9^{b c}$ & $0.306^{\mathrm{ab}}$ & $15.00^{\mathrm{ab}}$ \\
\hline $\begin{array}{l}\text { TG X 1904- } \\
6 F\end{array}$ & $334.4^{\mathrm{b}}$ & $9.44^{\mathrm{c}}$ & $39.0^{\mathrm{bc}}$ & $0.409^{\mathrm{ab}}$ & $16.33^{\mathrm{ab}}$ \\
\hline $\begin{array}{l}\text { TG X 1908- } \\
8 F\end{array}$ & $372.8^{\mathrm{ab}}$ & $12.33^{b c}$ & $38.1^{b c}$ & $0.313^{\mathrm{ab}}$ & $15.33^{\mathrm{ab}}$ \\
\hline $\begin{array}{l}\text { TG X 1910- } \\
13 F\end{array}$ & $224.6^{\mathrm{b}}$ & $11.67^{\mathrm{bc}}$ & $38.3^{b c}$ & $0.246^{\mathrm{ab}}$ & $33.00^{\mathrm{ab}}$ \\
\hline $\begin{array}{l}\text { Grand } \\
\text { Mean }\end{array}$ & 319.7 & 12.83 & 38.4 & 0.329 & 21.1 \\
\hline F-Prob & 0.015 & $<.001$ & $<.001$ & 0.196 & 0.326 \\
\hline LSD (0.05) & 208.51 & 2.275 & 6.00 & 0.173 & 24.97 \\
\hline CV\% & 39.1 & 10.6 & 9.4 & 31.4 & 70.9 \\
\hline
\end{tabular}

Means with different letters in a column are significantly different $(p<0.05)$ 


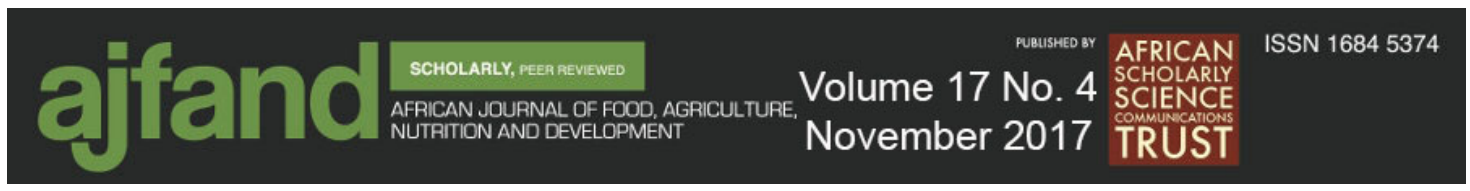

\section{REFERENCES}

1. Haghi Y, Boroomandan P, Moradin M, Hassankali M, Farhadi P, Farsaei F and S Dabiri Correlation and path analysis for yield, oil and protein content of Soybean (Glycine max L.) genotypes under different levels of nitrogen starter and Plant density. Biharean Biologist 2012; 6(1): 32-37.

2. Clemente TE and EB Cahoon Soybean Oil: Genetic Approaches for Modification of Functionality and Total Content. Plant Physiology 2009; 151: 1030-1040.

3. Filho MM, Destro D, Miranda LA, Spinosa WA, Carrão-Panizzi MC and R Montalván Relationships among Oil Content, Protein Content and Seed Size in Soybeans. Braz.arch. biol. technol. 2001; 44: 23-32. Accessed from http://dx.doi.org/10.1590/S1516-89132001000100004 on 12 May, 2015.

4. Eren A, Kocatürk M, Hos gün EZ and N Azcan Determination of seed yield, protein, oil content and fatty acid compositions and relationships of some soybean lines/cultivars.

ZiraatFakültesiDergisi

SüleymanDemirelÜniversitesi2012;7(1): 1-9.

5. Ghassemi-Golezani $\mathbf{K}$ and $\mathbf{S}$ Farshbaf-Jafari Influence of water deficit on oil and protein accumulation of soybean grains. International Journal of Plant, Animal and Environmental Sciences2012; 2(3): 46-52.

6. Dornbos Jr. DL and RE Mullen Soybean seed protein and oil contents and fatty acid composition adjustments by drought and temperature. J. Amer. Oil Chemists Soc. 1992; 69(3): 228-231.

7. Brock R Soybean Protein Content Low. Corn+Soybean Digest, 2008. Accessed from http://cornandsoybeandigest.com/soybean-protein-content-low on 20 July, 2015.

8. Chung J, Babka HL, Graef GL, Staswick PE, Lee DJ, Cregan PB, Shoemaker RC and JE Specht The Seed Protein, Oil, and Yield QTL on Soybean Linkage Group I. Crop Science 2003; 43: 1053-1067.

9. Hurburgh Jr. CR and TJ Brumm Protein and Oil Content of Soybeans Received at Country Elevators. Applied Engineering in Agriculture1990; 6(1):65-68.

10. Farshbaf-Jafari S, Pirzad A, Tajbakhsh $M$ and K Ghassemi-Golezani Effect of water supply and plant density on leaf characteristics of Amaranth (Amaranthus Caudatus L.). Paper Presented at the $2^{\text {nd }}$ International Conference on Sustainable Environment and Agriculture. IPCBEE 2014; 76:17-20. 
11. Maier DE, Reising J, Briggs JL, Day KM and EP Christmas High Value Soybean Composition, 1998. Accessed from http://www.extension.purdue.edu/extmedia/GQ/GQ-39.html1 on August, 2015.

12. Kananji G, Yohane E, Siyeni D and O Mulekano A guide to soybean production in Malawi. Malawi Government, Department of Agricultural Services, (DARS), 2013.

13. AOAC. Association of Official Analytical Chemists AOAC, Maryland. 2002.

14. Malik MFA, Ashraf M, Qureshi AS and A Ghafoor Utilization of Diverse Germplasm for soybean yield improvement. Asian Journal of Plant Sciences, 2006; 5(4):663-667.

15. Chandel KK, Patel NB and JB Patel Correlation coefficient and path analysis in soybean (GlycinemaxL.Merril).AGRES-An International e-Journal 2014;3(1): 25-3.

16. Song Q, Gai J and Y Ma Canonical correlation analysis and path coefficient analysisof protein content, oil content and yield of summer soybean landrace population from Mid-Yangtze River Valley. Soybean Sci. 1991.Accessed from http://en.cnki.com.cn/Article en/CJFDTOTAL-DDKX199102001.html on 3 August, 2015.

17. Yin $\mathbf{X}$ and TJ Vyn High soybean yield can mean higher concentration of isoflavones. Better Crops 2005; 89(4):13-15. 